\section{Francesco Sette takes over from Christof Kunz}

Francesco Sette, a well known figure at the ESRF, recently began his five-year term of office as one of the ESRF's Research Directors, succeeding Christof Kunz. Francesco has many firsts to his name. For the first time, ESRF appointed one of its resident staff to the Director's post. He has been the Head of the Inelastic X-ray Scattering Group at the ESRF for some 10 years. Prior to this, he was a staff member (1984-1990) at Bell Laboratories (Murray Hill, NJ, USA).

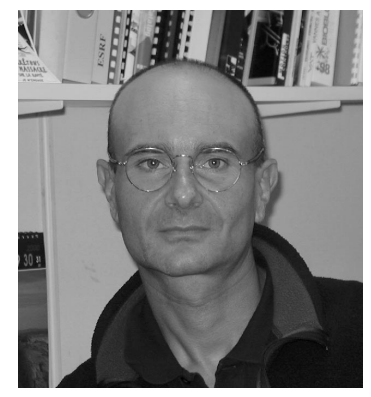

Francesco Sette.

\section{Roger Fourme becomes Life Science Director for SOLEIL}

Professor Roger Fourme, a synchrotron radiation pioneer and a founding member of the Journal of Synchrotron Radiation editorial board, became the Director of Life Science for SOLEIL, the new French third-generation source. Roger Fourme had been very forthright in his criticism of the former French science Minister, Claude Allègre, who, in August 1999, had announced the abandonment of the French project SOLEIL (see Editorial, November 1999).
Roger Fourme had established the first user facility for protein crystallography in Europe at the current french source, DCI, in 1976. $\mathrm{He}$ has been involved in several phasing methods for protein structure determination, especially MAD.

\section{APS gets a new head}

Dr Murray Gibson has been appointed Associate Laboratory Director for the Advanced Photon Source (APS), effective as of 22 October 2001. Dr Gibson has been the Director of the Materials Science Division at Argonne since 1998, where he has overseen Argonne's early efforts in nanosciences and fostered the development of the X-ray nanoprobe. Dr Gibson received his BSc (Physics) in 1975 from the University of Aberdeen, Scotland, and PhD in Physics from the University of Cambridge, England (1978). Prior to joining Argonne, he was at the University of Illinois, as a joint professor in the Departments of Materials Science and Engineering and Physics.

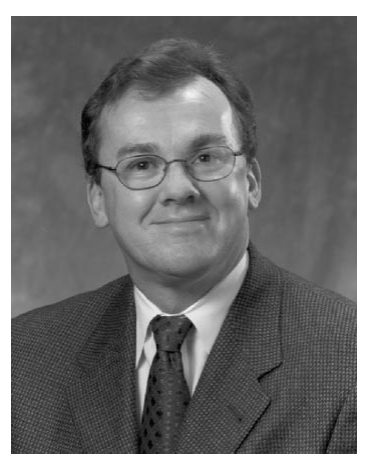

Dr Murray Gibson. 